\title{
DECONSTRUCTING POWER DYNAMICS AND PREVAILING DISCOURSES IN HYDROPOLITICS: THE CASE OF THE SIXAOLA RIVER BASIN
}

\author{
FATINE EZBAKHE ${ }^{1}$, CHRISTIAN BRÉTHAUT $^{1}$, TANIA RODRÍGUEZ-ECHEVARRÍA ${ }^{2} \&$ DIEGO JARA ${ }^{3}$ \\ ${ }^{1}$ University of Geneva, Institute for Environmental Sciences, Switzerland \\ ${ }^{2}$ University of Costa Rica, Centro de Investigación y Estudios Políticos, Costa Rica \\ ${ }^{3}$ Environmental Law Center, International Union for the Conservation of Nature, Germany
}

\begin{abstract}
The Sixaola river basin, shared between Costa Rica and Panama, is generally seen as one of the basins most prone to transboundary water cooperation. In the spotlight of the international community since the 1990s, the Sixaola basin has been framed as a prime example for multi-actor, multi-level, and multisector transboundary water governance, especially with the creation of the Binational Commission for the Sixaola River Basin (CBCRS for its name in Spanish). Still, one key question remains: who (and how) is behind such conceptual framing of the Sixaola basin? In other words, what actors have succeeded in defining the social reality of the Sixaola, and how has this reality affected the water governance? By looking at the discourses' evolution in the Sixaola basin, we aim to deconstruct the power dynamics underlining such discursive struggle. We employ Marteen Hajer's argumentative approach to discourse analysis to identify dominant storylines, practices and discourse coalitions, emphasising the role of international organisations. With this discursive approach, we examine how the Sixaola problem's boundaries (and ideas guiding the solutions to such problem) have changed in the past three decades. Our preliminary results show that international organisations have successfully framed the Sixaola "problematique" as local, while infusing it with a constant regional Central American perspective. Moreover, transboundary water governance has focused on sustainable economic practices to prevent biodiversity loss and land/water degradation, but with large banana companies at the margins. Finally, it remains unclear how international organisations have translated their discourses into national policies and regulations, beyond creating and strengthening the CBCRS as a platform for transboundary water cooperation.
\end{abstract}

Keywords: transboundary waters, water conflict and cooperation, discursive hydropolitics, Sixaola.

\section{SETTING THE SCENE: WHY TRANSBOUNDARY WATERS}

Transboundary waters are ubiquitous. 150 of the 196 countries worldwide share transboundary waters [1] with the 310 transboundary river basins covering $47 \%$ of the world's land surface and serving $52 \%$ of the world's population. In 52 countries - such as Afghanistan, Austria, Niger, and Paraguay - transboundary river basins cover more than $90 \%$ of countries' total surface [1]. Considering such numbers, it is no wonder that the UN Secretary-General Antonio Guterres, during the 2017 UN Security Council, stated that "it is essential that nations cooperate to ensure that water is shared equitably and used sustainably" and called for countries to "commit to investing in water security to ensure durable peace and security for all communities and nations". Indeed, the very nature of transboundary waters adds another layer of complexity when it comes to management. It requires more coordination - and collaboration - across countries, sectors, stakeholders, and scales, since mismanaging these waters raises a host of adverse effects, from water scarcity to poor water quality, environmental degradation, and economic losses to the communities relying on them.

To minimise the risk of mismanagement, the last decades have witnessed an emergence of rules and principles pushing transboundary water cooperation. From global conventions - such as the 1992 UNECE Water Convention and the 1997 UN Watercourses 
Convention - to bilateral and multilateral treaties, agreements, and arrangements, transboundary water cooperation has been put forward as a means to reconcile uses and reduce tensions that come from the use of such waters. The Global Environment Facility (GEF) alone has invested nearly 10 billion in grants and co-financing to strengthen cooperation on international and transboundary basins, the most recent one on institutionalising transboundary water management in the Panj river sub-basin, between Tajikistan and Afghanistan.

The last decades have also brought a shift in how we understand the actors in transboundary water governance. Rather than viewing transboundary waters as a purely States' affair, there has been an increasing realisation that their governance involves a myriad of non-state actors across a multitude of levels, both geographical and institutional. In other words, transboundary waters are a product of a fluid interaction between state and non-state actors, with the divide between them increasingly blurred due to the partnerships and multiactor platforms. We now speak of governmentality, not government [2], with non-state actors as integral part of the processes and outcomes of governing transboundary waters.

Out of all the non-state actors involved in transboundary water governance, in this paper, we put the spotlight on international organisations (IOs), including intergovernmental organisations (IGOs), international financial institutions (IFIs), and international nongovernmental organisations (INGOs). We aim to explore how these non-state actors shape the governance of transboundary waters. Instead of focusing on their resources, power, interests, and so on, we adopt a discursive lens to shed light on how IOs achieve to define the problems to be solved and propose the policy responses to those problems. In other words, by turning our attention to the IO's discourses, we can gain insight into how such actors participate in the construction of a basin's social reality through their projects, programmes, and initiatives.

We take the Sixaola river basin, shared between Costa Rica and Panama, as our case study. Based on Hajer's [3] argumentative approach to discourse analysis - that is, storylines, practices, and coalitions as our analytical variables - we examine how IOs have participated in the framing of the Sixaola problem's boundaries (and the ideas guiding the solutions to such problem) over the past three decades.

\section{WHY THE SIXAOLA RIVER BASIN}

There are 310 transboundary river basins, some of them notorious. The Nile, the Mekong, the Amazon, the Ganges-Brahmaputra-Meghna, the Tigris-Euphrates, the Rhine; such river basins have been the subject of many studies. The Sixaola river basin, on the other hand, is at the other end of the spectrum, with much less analyses devoted to it [4], [5]. Therefore, reflecting on why we choose the Sixaola - a basin no bigger than $3,000 \mathrm{~km}^{2}$ - as our case study is pertinent.

The Sixaola river basin remains "one of the most peaceful and prone to cross-border cooperation area in Central America", according to the European Commission [6]. Indeed, the relations between the two riparian countries, Costa Rica and Panama, do not resemble others in the isthmus. For instance, the Costa Rica-Nicaragua dynamics over the San Juan river basin are much more complex, underlined by unresolved territorial disagreements. The Costa Rica-Panama border has been undisputed since the 1941 Echandi-Fernández treaty, with several bilateral treaties signed in the 1970s and 1980s, from free trade (1973) and border protection and surveillance (1975) agreements to border cooperation (1979) and the creation of the La Amistad International Park (1982). Still, such peaceful diplomatic relations did not happen out of the blue. The 1941 border agreement arose after an armed conflict in the 1920s, known as the Coto War, which resolution came with the intervention of the United 
States and the involvement of U.S. banana companies (e.g., United Fruit Company and American Banana Company) operating in the region.

Yet, it is not the overall peaceful nature of the Costa Rica-Panama that makes the Sixaola river basin an intriguing case study for our research. Instead, it is its multi-dimensional nature, illustrated by its environmental, economic, and social value. First, this small basin is internationally recognised as a global biodiversity hotspot, both in terms of fauna and flora. Host of many endangered species receiving conservation priority, the Sixaola basin has attracted the attention of IOs dedicated to environmental conservation. Today, several protected areas cover the basin - the La Amistad International Park (PILA), Hitoy-Cerere Biological Reserve, Gandoca-Manzanillo National Wildlife Refuge, San San Pond Sack Wetlands and Palo Seco Protection Forest - accounting for more than half of the basin's surface. Second, the Sixaola basin is home to many indigenous and Afro-descendent communities, nearly $60 \%$ of the population. Despite this social value, the Sixaola is one of the most deprived regions in both countries, with human development indexes below the national averages. Third, the basin has an agriculture-based economy. Specifically, export banana production remains the central pillar of the basin's economy and employment source, despite the increasing efforts to diversify the agriculture to alternative crops (mainly cacao, pineapple, tubers and fruit trees), and notwithstanding the negative environmental consequences from the intensive consumption of agrochemicals. This multi-dimensional and somewhat complex nature makes the Sixaola basin an attractive case study.

What is more, due to this very multi-dimensional makeup, the Sixaola basin has become an ideal candidate for international cooperation. Deemed by some as the "laboratory for cooperation", the Sixaola has stirred the interest of different intergovernmental organisations, international NGOs, and cooperation agencies. Since the early 1990s, the history of the Sixaola is replete with initiatives and projects proposed, funded, or implemented by international organisations, mainly dedicated to environmental conservation and sustainable development. For instance, as recently as in 2019, the GEF has approved a concept note for an 18 million project on "transboundary integrated water resource management" in the Sixaola river basin.

If we understand transboundary water governance in the broad sense - that is, as a multiactor, multi-level, and multi-dimensional process - the Sixaola constitutes an ideal candidate for exploring how IOs have shaped the basin's social reality and how this reality translate in the way it is government. As several IOs have framed the Sixaola as a "first step", a justification to enter in more complex basins, it is right to use it as an excellent first study for our research purposes.

\section{OUR ANALYTICAL FRAMEWORK}

While there are many different approaches to do discourse analysis, we use Hajer's argumentative analysis as our source of inspiration, which entails two key elements. First, we see discourse analysis not only in its linguistic dimension - i.e., what we say or write but mainly in its performative and practical dimensions - i.e., what are the practices through which we produce and reproduce what we say. In other words, for us, discourse analysis is about meaning, not language, and about the dynamic processes of meaning production. Second, to undertake discourse analysis, we use three factors: storylines, practices, and discourse coalitions. Storylines are a "generative sort of narrative that allows actors to draw upon various discourse categories to give meaning to specific physical or social phenomena". Thus, storylines serve as easy representations of an issue and help actors make their arguments. Practices are "through which meaning is given to physical and social realities", how actors translate or communicate a particular storyline. Finally, discourse coalitions are 
the "ensemble of a set of storylines, the actors that utter these storylines, and the practices that conform to them". Actors in the same discourse coalitions might not know each other, but they use the same argument and set of practices.

With this approach, the questions to answer are thus: (1) what storylines IOs use as arguments to their actions in the Sixaola? (2) what practices they use to turn these storylines into reality? and (3) what coalitions emerge from these storylines and practices? We will not cover the last question in the present paper, though, as it remains the object of ongoing work. We base our analysis on secondary documentation on the initiatives, projects and strategies financed and implemented by IOs in the Sixaola, complemented with semi-structured interviews with key actors to triangulate the information.

\section{THE DISCURSIVE STRUGGLE IN THE SIXAOLA: AN EVOLUTION}

1941, with the signing of the Border Agreement between Costa Rica and Panama, marks what both parties describe as a period of "friendship, cooperation, good neighbourliness, and peace" [1]. Yet, if one pays a closer look at what has happened since 1941 in the Sixaola, particularly from the discursive lens, three phases stand out: (1) Phase 1 (1970s-1995), with a focus on regional integration and peace; (2) Phase 2 (1995-2005), with an emphasis on biodiversity conservation; and (3) Phase 3 (2005-2015), with a momentum for local water governance. While the three phases are distinct, the start and end dates are not fixed but rather an interpretative and simplified depiction. In reality, the phases - and the discourses underlying them - overlap.

\subsection{Phase 1 (1970s-1995): Towards regional integration and peace}

The 1970s-1990s decades were ones of border agreements, which went beyond the Sixaola, and focused on peace and cooperation. The peace discourse is crystal clear in the first border agreement signed: the 1979 Agreement on Border Cooperation. While the 1979 Agreement puts border cooperation as a vital ingredient for socio-economic development, it also puts such cooperation in the context of the "fraternal ties between the countries". The 1979 Agreement thus links socio-economic development in the border with overall peaceful interactions between the two countries and aims to "adopt the pertinent measure to improve the region in all aspects and to regularize commercial exchange for mutual benefit". The same year, the two Governments signed the 1979 Joint declaration on the creation of the La Amistad International Park (PILA). The discourse framing the creation of this park is also in terms of peace: not only is the park explicitly labelled as a "friendship park", but more importantly, the park becomes a reflection of the "excellent relationships of friendship and brotherhood between the two peoples and governments", a way to "continue cooperation in the border area" and "conserve and preserve flora and fauna of the region". Under this discourse of "peace" and "friendship", the two countries then signed the 1992 Agreement on Cooperation for Border Development, which exists till this day. As with the previous two, this agreement builds on the "fraternal ties of friendship, mutual understanding and democratic vocation", with the aim of "broadening, improving and deepening the cooperative relations in all fields", contributing to the development in its different dimensions, i.e., "social, commercial, environmental and political improvement". At first glance, these three agreements seem to be a State-driven initiative, an endeavour between two States based on a discourse of peace and friendship. However, such agreements do not happen in a vacuum but are thoroughly situated in a regional context.

By looking at the Central American regional context, we can uncover how this discourse of peace and friendship is attached to a broader one, shaped mainly by IOs. Specifically, all 
three previous agreements stemmed from IOs-driven initiatives at the regional level. The 1979 Agreement on Border Cooperation, for instance, could not have been possible without the role of the Inter-American Development Bank (IDB), a multilateral financial institution established in 1959 to finance "economic and social development" in Latin America and the Caribbean. The 1979 Agreement resulted from a 1971 Study for Integrated Development of the Border Region, funded with the IDB's the Pre-investment Fund for the Integration of Latin America created in 1966. The discourse of regional integration is very evident in the Fund's aim, which targets "studies that enable the identification and preparation of multinational projects in all areas that are important to promote regional integration". While the two Governments never completed the 1971 IDB-funded study, they used it as the basis for developing the 1979 Agreement. IOs were also involved in the shaping of the 1979 Joint Declaration of the creation of the PILA. Five years before the declaration, the International Union for the Conservation of Nature (IUCN) organized the First Central American Meeting on Natural and Cultural Resource Management. The 1974 meeting brought together governments of the countries and experts from concern IOs (UNEP, FAO, UNESCO, WWF, CATIE) to "develop an action programme for an integrated regional system of national parks and equivalent reserves". One of the seven recommendations resulting from the discussions put the spotlight on "border areas that are particularly well suited to be frontier parks between neighbouring countries". Furthermore, we cannot understand the 1992 Agreement on Cooperation for Border Development without considering the role of the Central American Integration System (SICA). This economic and political organization, created in 1991, embodied "a new vision of Central America as a region of peace, democracy, and development", a way to overcome the turmoil and violence witnessed in the region in the 1980s. In 1992, the "Foro de Vicepresidentes Centroamericanos", a body of the SICA, emphasized the border development in the region and supported the elaboration of a regional action plan for "border development and integration". Thus, it is not surprising that the discourse of peace and friendship found in the 1992 Agreement is similar to other agreements signed in this period, such as the 1992 Trifinio Plan and the 1993 Treaty for the Execution of the Trifinio Plan.

Thus, in this first phase, we can identify three distinct storylines:

- Storyline 1: Regional integration as a "requisite" for sustainable peace and cooperation. Regional integration is both a goal and a means to achieve long-term and sustainable peace and cooperation.

- Storyline 2: Border regions as "ideal" spaces for cooperation and development. Border areas are no longer seen as conflict-prone areas to avoid but as the perfect spaces for strengthening cooperation. Under this rationale, border areas are the first step to achieving regional integration through frontier parks.

- Storyline 3: Development from a socio-economic perspective. Peace and development are tools for socio-economic improvement. Even frontier parks are not about protecting the environment per se, but about improving the wellbeing of the people living in these border areas.

In this same phase, we can identify three concrete practices that IOs used to utter the storylines:

- Practice 1: Institution creation. The most important institution created was the SICA, aimed at regional integration, but IOs also supported the establishment of binational and trinational governance structures. 
- Practice 2: Agreements and treaties. The agreements and treaties signed in the early 1990s followed the discourse on regional integration and peace.

- $\quad$ Practice 3: High-level meetings. In particular, the meeting organised by IUCN translated into the creation of binational parks.

Finally, in terms of discourse coalitions, all IOs followed similar discourses, without any opposing storylines.

\subsection{Phase 2 (1995-2005): Emphasis on biodiversity conservation}

Furthermore, the Sixaola soon became a piece of the regional biodiversity conservation puzzle. Since the 1995s, the Sixaola became host of a series of regional environmental projects - including the Parks in Peril, Regional Environmental and Natural Resources Management (RENARM), Regional Environmental Program for Central America (PROARCA), and the Mesoamerican Biological Corridor (MBC) - funded by IOs. All these projects followed a similar discourse, one of "minimising damage to the environment, protecting biodiversity, and providing the means for equitable and sustainable economic growth" and of "creating local capacity for the conservation of threatened, high-biodiversity landscapes". Rather than the multi-dimensional approach promoted by the Binational Governance bodies, this string of projects emphasised the environment. Plus, these projects introduced a new discursive element: a need for creating local capacities, not for decisionmaking but somewhat operational, for the conservation of biodiversity landscape. However, these environmental projects came in juxtaposition with the Plan Puebla Panama, a regional investment plan launched in 2000 to promote "productive investment to boost economic development and overcome poverty" and attract "productive private investment to the region". In the 2000-2006 period, the Plan Puebla Panama funded more than 33 megaprojects, totalling USD 4,500 million, most of them for transportation and energy infrastructure. Some scholars describe it as a "neoliberal vision of development" [7], [8], contradicting the biodiversity conservation discourse promoted by IOs.

In this second phase, the storylines of IOs evolve into:

- Storyline 1: Biodiversity of the region as a "global ecological issue". In a sense, biodiversity loss in Central America concerns the whole world, making it a priority of IOs.

- Storyline 2: Environmental conservation and protection as a goal. The preservation and protection of ecosystems is, in itself, a goal to achieve, for the sake of the environment.

- Storyline 3: Environmental conservation and protection as a means. Natural resources are assets with socio-economic value and thus need to be conserved because to "boost" socio-economic development.

In terms of practices of the IOs, we can distinguish two main ones:

- Practice 1: Development cooperation projects. INGOs and States' foreign aid agencies employed projects to make environmental conservation a reality in the Sixaola.

- Practice: Investment strategies and funds. Regional institutions and banks employed regional investment strategies, most importantly the Plan Puebla Panama, to put environmental conservation part of the socio-economic development of the region.

In this sense, two discourse coalitions emerge. On the one hand, there is the coalition of INGOs, where biodiversity conservation remains a goal, that is, conserving ecosystems for the sake of ecosystems. On the other hand, the coalition of most regional banks and 
institutions frames biodiversity conservation as means to achieve socio-economic development.

\subsection{Phase 3 (2005-2015): A momentum for local governance.}

The third phase kicks off with the two national projects for the Sixaola: the Program of sustainable development of the Sixaola river binational basin in Talamanca (Costa Rica) and the Multiphase program of sustainable development in Bocas del Toro in Bocas del Toro (Panama). Both projects, each in one part of the basin, emerged from the Executive Secretariats' efforts of the 1992 Agreement on Cooperation for Border Development. They were "interventions in the economic, social, and environmental spheres" to contribute to a "sustainable development model". While the discourse on the three pillars of sustainable development is not new, the two projects added a new element to the Sixaola's discursive evolution: the need for pilot projects aimed at productive diversification. Specifically, the projects promoted organic cacao as an alternative to banana monocultures, but exclusively in small farms, leaving the large banana companies outside of the projects' scope. In 2006, the Executive Secretariats went one step further by approaching the Global Environment Facility (GEF) for funding a binational project, covering the basin as a whole. The process of developing this binational project framed the "Sixaola problem" as one of "limited sustainable livelihoods, unsustainable economic activities, and institutional limitations" and the "Sixaola solution" being institutional strengthening, but without the creation of new institutions. However, this discourse shifted when the GEF-funded Binational Sixaola Project on Integrated Management of Ecosystems started in 2008. The project required the creation of a binational commission to provide "strategic direction" to the project and be responsible for its supervision. The reasons behind this discursive change remains unclear but can be found in other GEF-funded projects, where local commissions are requirements to foster participation. Due to this requirement, the countries created the Binational Commission of the Sixaola River Basin (CBCRS) in 2009, with another spin in the discourse: first, it was not a requirement, but a choice by the actors involved to have a body under the umbrella of the 1992 Agreement; second, it was no longer for project supervision, but for a "long-term vision of becoming a unit for local planning and management of the basin". Furthermore, as in the previous phase, the Sixaola was host to a series of regional projects, including Alliances, Water Management for Adaptation, Adaptation, Vulnerability and Ecosystems (AVE), and Building River Dialogue and Governance (BRIDGE), all implemented by IUCN. All these projects followed the same discourse: that local capacity building is critical for facilitating transboundary water cooperation since there are more opportunities for change at the local level. In the Sixaola, IUCN-projects targeted the strengthening of the Binational Commission, aiming to make it a "platform" for multi-actor (including indigenous communities) and multi-sectoral (including tourism and economic practices) decision-making. Finally, in 2010, the adoption of the "Central American Strategy for Rural Development" (ECADERT) represented a different shift in the discourse. First, the focus was no longer on border areas but rural territories (although the strategy included border areas such as the Sixaola because of their rural and peripheral nature). Second, there was an emphasis on public policies instead of projects. Third, there was an explicit promotion of organic cacao production to achieve "inclusive economies for rural territories".

The storylines emerging from these projects and strategies are:

- Storyline 1: Local governance as key to inclusive transboundary water governance. The rationale is that, since governance happens at the local level - both formal and informally 
- it is necessary to bring together all the different actors and sectors and foster dialogue between them.

- Storyline 2: Unsustainable economic activities as a root cause. Issues such as biodiversity loss and water degradation cannot be separated from the unsustainable agricultural practices in the basin. Still, the storyline does not shed light on all the actors behind such agricultural practices (large banana companies in particular).

- Storyline 3: Institutional strengthening as a requirement for sustainable development. Institutions - at the local level, in particular - lack human and financial capacities, and thus strengthening them becomes the first and must-do step towards achieving sustainable development.

Again, there are two distinct practices that IOs used to utter these storylines:

- Practice 1: Development cooperation projects. Most of these projects focused on the strengthening of the Binational Commission.

- Practice 2: Direct advice, support, and technical assistance.

As in the first phase, there are no opposing discourse coalitions. All IOs subscribe to the discourse of local water governance as both a goal and means for the basin's sustainable management.

\section{THE DISCURSIVE STRUGGLE IN THE SIXAOLA: AN EVOLUTION}

In this paper, we analysed the discursive struggle in the Sixaola river basin, particularly the role of IOs in the boundaries and framings of the problem and the ideas for the solutions proposed. From our analysis, we can highlight the following aspects:

- Boundaries. The regional perspective has been a constant in all discursive phases. The "Sixaola problem" is not only bounded to the Sixaola basin, but linked to other basins in Central America. In the last phase, we see an increasing focus on the local level, especially for inclusive governance processes.

- Conceptual framings. The root cause of the "Sixaola problem" lies in the unsustainable economic practices, mainly in the agricultural sector, and hence the efforts towards organic cacao. Yet, throughout the years, the discourse of IOs miss a critical piece of the puzzle: the large banana companies present in the basin.

- Ideas guiding the "Sixaola solutions". What started as signing treaties and agreements slowly evolved into multi-actor platforms, now focusing exclusively on the Binational Commission. Still, this operationalisation of the solutions has always focused on projects instead of public policies. This reflects that the discursive power of IOs has been through the formulation and implementation of projects and leaves the question of why not public policies.

\section{ACKNOWLEDGEMENTS}

We thank the interviewees who generously gave their time in order to contribute to this research. This research is part of a broader project on Monitoring for International Hydropolitical Tensions, jointly developed by the University of Geneva, Oregon State University, Tufts University, and the International Union for the Conservation of Nature.

\section{REFERENCES}

[1] McCracken, M. \& Wolf, A.T., Updating the register of international river basins of the world. International Journal of Water Resources Development, 35(5), pp. 732-782, 2019. 
[2] Foucault, M., Governability. The Foucault Effect: Studies in Governmentality, eds G. Burchell, C. Gordon \& P. Miller,. The University of Chicago Press: Chicago, USA, pp. 87-104, 1991.

[3] Hajer, M.A., The Politics of Environmental Discourse: Ecological Modernization and the Policy Process, Oxford University Press, 1995.

[4] Rodríguez-Echevarría, T., Gobernanza ambiental en cuencas transfronterizas: la cuenca del río Sixaola (Costa Rica-Panamá), Iztapalapa Revista de Ciencias Sociales y Humanidades, 87(40), pp. 71-99, 2019.

[5] Rodríguez-Echevarría, T., Obando, A. \& Acuña, M., Entender el extractivismo en regiones fronterizas: Monoculuvos y despojo en las fronteras de Costa Rica. Revista Sociedad y Ambiente, 6(17), 2018.

[6] European Commission, EU - Central America Cooperation: Support to the Central American Integration System's (SICA) cross-border cooperation actions. Final Report. Association of European Border Regions (AEBR), 2014.

[7] Cadena-Montenegro, J.L., El Plan Puebla Panamá: ¿La reconolización de América Latina? Revista de Relaciones Internacionales, Estrategia y Seguridad, 1(2), pp. 121$155,2006$.

[8] Ken-Rodríguez, C.A., La iniciativa de integración del Plan Puebla Panamá: consideraciones desde la postura del desarrollo regional equilibrado de Mesoamérica, Economía y Administración, 2(2), pp. 95-126, 2017. 